\title{
REGENERATION OF CHRONIC WOUNDS WITH ALLOGENEIC PLATELET GEL VERSUS HYDROGEL TREATMENT: A PROSPECTIVE STUDY
}

\author{
Danijela Semenič ${ }^{1}$, Tina Cirman ${ }^{2}$, Primož Rožman ${ }^{2}$ and Dragica Maja Smrke ${ }^{1}$ \\ ${ }^{1}$ Department of Surgical Infections, University Medical Centre Ljubljana, Ljubljana, Slovenia; \\ ${ }^{2}$ Blood Transfusion Centre of Slovenia, Ljubljana, Slovenia
}

\begin{abstract}
SUMMARY - The aim of the study was to evaluate the efficacy and safety of the new method of platelet-rich plasma activation in the form of platelet gel, used in the treatment of non-healing chronic lower leg ulcers. The study was prospectively randomized, double blind and placebo controlled. We treated 60 patients ( 42 males and 18 females, mean age 69.43 years, SD 14.74) with chronic lower leg ulcers of different etiologies. Thirty patients were treated with allogeneic platelet gel and 30 with hydrogel. Both groups were comparable for duration of ulcer and its size. Treatment was repeated once a week for three consecutive weeks and then the last examination was scheduled at 6 months of the first platelet gel application. The t-test was used to analyze independent samples. Healing of chronic wounds with platelet gel was statistically significantly more effective compared to the treatment with hydrogel $(\mathrm{p}<0.05)$. At 6 months of platelet gel application, the mean wound area in the experimental group decreased to $35.01 \%$ (SD 53.69) of the initial wound size. In the control group, the wound area decreased to $89.95 \%$ (SD 71.82) of the initial wound size ( $\mathrm{p}=0.001$ ). The circumference of the wounds diminished to $54.62 \%$ (SD 39.85) of the initial value in the experimental group, compared to $91.28 \%$ (SD 29.32) in the control group ( $\mathrm{p}<0.001)$. Allogeneic platelet gel prepared by the new method used in this study was found to be a good treatment option for non-healing chronic wounds when other methods are ineffective.
\end{abstract}

Key words: Platelet-rich plasma; Leg ulcer; Wound healing

\section{Introduction}

Platelets are small $(1-3 \mu \mathrm{m})^{1}$, anuclear cell fragments, derived in bone marrow from megakaryocytes by cellular fragmentation ${ }^{2-5}$. Platelet differentiation is directed by several growth factors, the most notable one being thrombopoietin ${ }^{2}$. Their lifespan is $7-9$ days $^{3}$, and the concentration of platelets in peripheral blood of a healthy adult is $150-350 \times 10^{9} / \mathrm{L}^{2,6,7}$.

Platelets contain at least 60 biologically active, presynthesized molecules, e.g., cytoskeletal proteins, sig-

Correspondence to: Danijela Semenič, $M D$, Department of Surgical Infections, University Medical Centre Ljubljana, Zaloška cesta 7, 1000 Ljubljana

E-mail: danijela.semenic@kclj.si

Received June 26, 2017, accepted October 10, 2017 naling molecules, membrane protein, growth factors, coagulation proteins, adhesion molecules, cell-activating molecules, cytokines, integrins, inflammatory molecules, and others ${ }^{2,3,8}$. These molecules are stored in one of the three main types of platelet granules. The first form of granules are dense granules. There are 3-8 dense granules per platelet; they are released by exocytosis and contain several active substances (adenosine diphosphate/adenosine triphosphate (ADP/ATP), serotonin, $\left.\mathrm{Ca}^{2+}\right)^{9,10}$. There are 50-80 alpha $(\alpha)$ granules per platelet $^{10,11}$, and they release a plethora of different growth factors, chemokines and cytokines ${ }^{9,10}$. Although there are more than 300 different proteins in $\alpha$-granules ${ }^{11,12}$, it seems that the most important growth factors in platelets are the three isomers of platelet-derived growth factor (PDGF) $\alpha \alpha, \beta \beta$ and $\alpha \beta$, 
transforming growth factor (TGF) $-\alpha$ and $-\beta$, vascular endothelial growth factor (VEGF) and epidermal growth factor (EGF), since they initiate wound healing ${ }^{13,14}$.

Also of importance are other growth factors found in platelets, i.e. fibroblast growth factors (FGFs), insulin-like growth factor (IGF), platelet-derived endothelial growth factor (PDEGF), platelet-derived angiogenesis factor (PDAF), interleukin-8 (IL-8), tumor necrosis factor (TNF)- $\alpha$, granulocyte-macrophage colony-stimulating factor (GM-CSF), keratinocyte growth factor (KGF) and angiopoietin-2 (Ang-2)2. All of the above-mentioned growth factors participate in tissue healing, influencing mechanisms such as chemotaxis, cell proliferation, cell differentiation, removal of cell debris, angiogenesis, immune modulation, antimicrobial activity and tissue remodeling ${ }^{2,3,11,15}$. The last type of platelet granules are lysosomes that contain enzymes responsible for protein induction and matrix regeneration (cathepsins $\mathrm{D}$ and $\mathrm{E}$, elastase, acid hydrolases) $)^{9,10,16}$

When platelets adhere to the exposed molecules of injured epithelium or bind physiological agonists such as thrombin, ADP, collagen, thromboxane A2, epinephrine or platelet-activating factors, they get activated $^{3}$. This process leads to rapid shape change of the platelet, to development of pseudopodia because of cytoskeleton reorganization, and finally to platelet aggregation $^{1,2}$.

Platelet activation also causes release of the contents of $\alpha$-granules into the surrounding environment due to their fusion with platelet plasma membrane, known as degranulation ${ }^{10,17}$. The majority (95\%) of the pre-synthesized contents of platelet granules is released within 1 hour of the activation, while additional growth factors are synthesized and released until the end of the platelet lifetime ${ }^{13}$.

Besides their role in hemostasis, where platelets help prevent blood loss at the site of injury, they also play an important role in immune defense, tissue forming and regeneration ${ }^{2,10,16}$. Because of these findings, platelets were started to be successfully used for faster healing of chronic wounds. To date, there are only few studies that focus on the effectiveness of the use of the autologous platelet rich plasma (PRP) and platelet gel for the purpose of accelerating healing of chronic wounds. The aim of this study was to expand the knowledge about PRP and to evaluate the efficacy and safety of the new method of PRP activation into a platelet gel used for the treatment of non-healing chronic lower leg ulcers.

\section{Patients, Materials and Methods}

Throughout the procedure, local and European regulations and restrictions for tissue and cell products were followed. Both participating institutions (University Medical Centre Ljubljana and Department of Surgical Infections and Blood Transfusion Centre, Slovenia) acquired an accreditation by the Public Agency of the Republic of Slovenia for Medicinal Products and Medical Devices. The Republic of Slovenia National Medical Ethics Committee approved the study.

Sixty patients (42 males and 18 females, mean age 69.43 years, SD 14.74) with chronic ulcer of different etiology on lower extremity were enrolled in the prospective randomized controlled double blind trial. Thirty patients were treated with allogeneic platelet gel (experimental group) and 30 patients in control group with placebo hydrogel (Tegaderm; 3M, USA). The patients in both groups were comparable for ulcer duration and ulcer size (mean area $14.51 \mathrm{~cm}^{2}$, SD 23.14, range $0.1-136.2 \mathrm{~cm}^{2}$; mean circumference $13.53 \mathrm{~cm}$, SD 10.77, range 1.6-53.8 cm). In both groups, we treated venous ulcers $(n=12)$, arterial ulcers $(n=12)$, diabetic ulcers $(\mathrm{n}=30)$ and non-healed ulcers following injury $(n=6)$. Inclusion criteria were absence of local and systemic signs of inflammation, previous known malignancy, autoimmune diseases and absence of pregnancy. Laboratory parameters in the majority of patients before treatment (differential blood count, electrolytes, urea, creatinine, albumins, proteins, iron, C-reactive protein, erythrocyte sedimentation rate, liver function tests, tests of hemostasis) were within the normal limits. No anti-platelet antibodies were detected in the blood of any patient.

Blood group of the platelet gel recipient was determined ( $\mathrm{ABO}, \mathrm{RhD})$. After identification of a possible donor (matching $\mathrm{ABO} \mathrm{RhD}$ group), her/his written consent was obtained and blood was drawn to test for the presence of viral markers. Since platelet gel was considered a tissue/cell product, tests were performed as required by local regulations, including lues, hepatitis $B$ surface antigen $(\mathrm{HBs} \mathrm{Ag})$, antibodies to the hepatitis $\mathrm{B}$ core antigen (anti- $\mathrm{HBc}$ ) and hepatitis $\mathrm{B}$ surface 
antigen (anti-HBs), hepatitis $\mathrm{C}$ antibody (anti-HCV), combined testing for human immunodeficiency virus antibody and $\mathrm{p} 24$ antigen (anti-HIV 1/2/0,HIVp24Ag), hepatitis $\mathrm{B}$ virus DNA (HBV DNA), hepatitis $\mathrm{C}$ virus RNA (HCV RNA) and HIV1 RNA.

Buffy coat was released from the quarantine when the donor blood sample was reported to be negative for viral markers and it was confirmed that the blood group of a donor matched that of a platelet gel recipient. Further processing started no later than 24 hours after the blood drawing. Buffy coat of the donor's blood was irradiated with $30 \mathrm{~Gy}$ from a Cs-137 source, using the Gammacell 1000 Elite (Best Theratronics, Canada) irradiation device.

After irradiation, processing continued in clean rooms (grade A-grade $\mathrm{D}$ environment as required by local regulation for tissue/cell processing). Buffy coat was transferred to the centrifuge tube and spun at $1500 \mathrm{~g}$ for 8 minutes without a break. The top-most layer (PRP) was transferred to the fresh tube. PRP was sampled for sterility testing using a Becton Dickinson Bactec 9050 (Becton Dickinson, USA) system and the platelet, red and white blood cell count was measured. PRP was stored at room temperature until platelet activation. All PRPs were used within 24 hours of preparation.

Outpatient treatment was performed at the outpatient unit of the Department of Surgical Infections, University Medical Centre Slovenia. At the beginning of the study, blood laboratory testing was performed and swabs of the wounds for microbiological examination were collected. Patients were examined once a week. Platelets in PRP were activated in the aseptic operating room using adjusted doses of components Beriplast $\mathrm{P}$
Combi-Set $1 \mathrm{~mL}$ : thrombin $500 \mathrm{IU} / \mathrm{mL}+40 \mathrm{mmol}$ $\mathrm{CaCl} 21 \mathrm{~mL}$ + aprotinin $100 \mathrm{KIU}$ (Kallikrein Inactivator Unit, corresponding to $0.056 \mathrm{PEU}, \mathrm{PEU}=\mathrm{Ph}$. Eur Unit, $1 \mathrm{PEU}=1800 \mathrm{KIU})+$ fibrinogen $9 \mathrm{mg}+$ coagulation factor XIII 6U (1 Unit (U) corresponds to Factor XIII activity of $1 \mathrm{~mL}$ fresh citrated plasma, pooled plasma of healthy donors). Gelatinous mixture (i.e. platelet gel) was formed within 5 minutes after the addition of activation components and was applied to the cleaned wound no later than 5.5 minutes after PRP activation.

After wound irrigation with the local antiseptic solution polyhexamethylenebiguanide (PHMB) 0.1\% with Betaine 0.1\% (Prontosan; B Braun, Germany) and sharp cleaning with the gauze, platelet gel or hydrogel (Tegaderm; 3M, USA) were applied to the wound bed and covered with silicone-polyurethane wound dressing (Mepilex; Mölnlycke, Sweden). The surrounding skin was protected using a neutral fat cream ( $20 \%$ olive oil in linola fat). Treatment was repeated once per week for three consecutive weeks. Digital photos of the wounds were obtained every week before gel application.

For wound image analysis, specially developed digital image analysis algorithm, Wound ManagerTM, based on artificial intelligence, was used. Wound area, circumference, and wound healing rate $(\mathrm{WH}$, calculated as relative weekly change of wound area) were presented graphically and numerically. The information about percentages of different tissue types within the wound (granulation tissue, fibrin, necrosis) were manually marked on the selected wound photographs. At the end of the study, blood laboratory examination and swabs of the wounds for microbiological examination were performed again (Tables 1 and 2).

Table 1. Laboratory blood values before and after treatment

\begin{tabular}{|c|c|c|c|c|c|c|c|c|}
\hline & \begin{tabular}{|l|} 
Mean \\
platelet \\
count \\
before \\
$\left(10^{9} / \mathrm{L}\right)$
\end{tabular} & \begin{tabular}{|l} 
Mean \\
platelet \\
count \\
after \\
$\left(10^{9} / \mathrm{L}\right)$
\end{tabular} & $\begin{array}{l}\text { Mean } \\
\text { leukocyte } \\
\text { count } \\
\text { before } \\
\left(10^{9} / \mathrm{L}\right)\end{array}$ & $\begin{array}{l}\text { Mean } \\
\text { leukocyte } \\
\text { count } \\
\text { after } \\
\left(10^{9} / \mathrm{L}\right)\end{array}$ & \begin{tabular}{|l} 
Mean \\
CRP \\
value \\
before \\
$(\mathrm{mg} / \mathrm{L})$
\end{tabular} & $\begin{array}{l}\text { Mean } \\
\text { CRP } \\
\text { value } \\
\text { after } \\
(\mathrm{mg} / \mathrm{L})\end{array}$ & \begin{tabular}{|l} 
Mean \\
ESR \\
value \\
before \\
$(\mathrm{mm} / \mathrm{h})$
\end{tabular} & $\begin{array}{l}\text { Mean } \\
\text { ESR } \\
\text { value } \\
\text { after } \\
(\mathrm{mm} / \mathrm{h})\end{array}$ \\
\hline $\begin{array}{l}\text { Experimental } \\
\text { group }(\mathrm{n}=30)\end{array}$ & $\begin{array}{l}263.73 \\
\text { (SD 63.49) }\end{array}$ & $\begin{array}{l}264.26 \\
\text { (SD 74.51) }\end{array}$ & $\begin{array}{l}7.59 \\
\text { (SD 2.02) }\end{array}$ & $\begin{array}{l}7.32 \\
\text { (SD 1.76) }\end{array}$ & $\begin{array}{l}11.60 \\
\text { (SD 10.28) }\end{array}$ & $\begin{array}{l}9.16 \\
\text { (SD 10.54) }\end{array}$ & $\begin{array}{l}30.74 \\
\text { (SD 26.09) }\end{array}$ & $\begin{array}{l}31.47 \\
\text { (SD 22.73) }\end{array}$ \\
\hline $\begin{array}{l}\text { Control } \\
\text { group }(n=30)\end{array}$ & $\begin{array}{l}315.10 \\
\text { (SD 33.53) }\end{array}$ & $\begin{array}{l}310.50 \\
\text { (SD 45.00) }\end{array}$ & $\begin{array}{l}7.51 \\
\text { (SD 1.08) }\end{array}$ & $\begin{array}{l}7.61 \\
\text { (SD 0.77) }\end{array}$ & $\begin{array}{l}10.00 \\
\text { (SD 5.87) }\end{array}$ & $\begin{array}{l}8.83 \\
\text { (SD 5.31) }\end{array}$ & $\begin{array}{l}19.83 \\
\text { (SD 9.72) }\end{array}$ & $\begin{array}{l}17.83 \\
(\mathrm{SD} 7.28)\end{array}$ \\
\hline $\mathrm{p}$ & $<0.001$ & 0.005 & 0.849 & 0.413 & 0.462 & 0.878 & 0.036 & 0.003 \\
\hline
\end{tabular}

$\mathrm{CRP}=\mathrm{C}$-reactive protein ESR = erythrocyte sedimentation rate; $\mathrm{SD}=$ standard deviation; $\mathrm{p}=$ level of statistical signifficance of between-group differences 


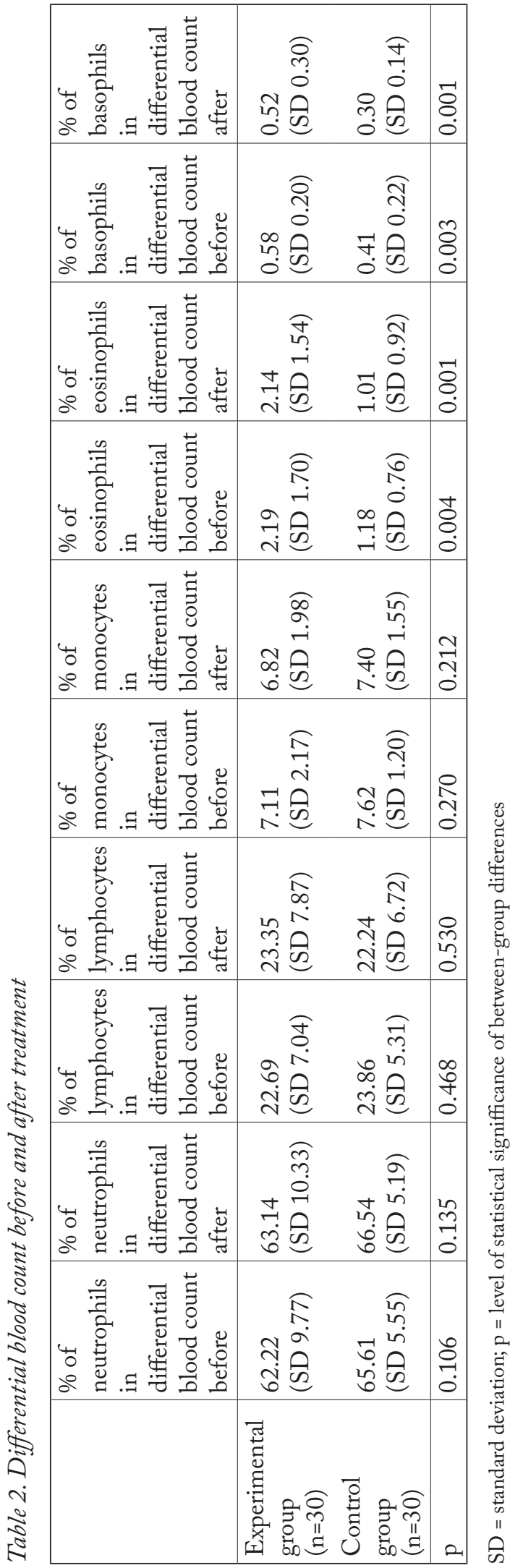

\section{Statistical analysis}

Student's t-test was used to analyze differences between the groups. All analyses were performed by use of PASW statistics 18.0 (IBM, USA). Healing of chronic wounds was assessed by calculating the percentage of the mean wound area and circumference reduction at 6 months of treatment as compared with the values recorded before treatment.

\section{Results}

Six months after first platelet gel application, the mean area of the wounds in experimental group decreased to $35.01 \%$ (SD 53.69) of the initial value compared to $89.95 \%$ (SD 71.82) in control group, $\mathrm{p}=0.001$. Circumference of the wounds was reduced to $54.62 \%$ (SD 39.85) of the initial value for experimental group and to $91.28 \%$ (SD 29.32) for control group, $\mathrm{p}<0.001$. Healing of chronic wounds with platelet gel was statistically significant when compared to the treatment with hydrogel $(\mathrm{p}<0.05)$ (Fig. 1).

Laboratory blood values and inflammation parameters in the blood were in the normal limits for both groups and did not vary significantly before and after treatment (Tables 1 and 2). In addition, the type of bacteria has not changed statistically significantly before and after treatment (Table 3).

None of the patients treated with platelet gel developed maceration of the surrounding skin, while maceration was observed in $75 \%$ of patients in the control group despite the skin being protected with oily cream.

No systemic or local side effects or adverse reactions were observed during the topical treatment, and no platelet antibodies were detected in the systemic blood circulation of the patients who had received platelet gel.

\section{Discussion}

Traditionally, platelet activation is achieved by adding thrombin and calcium to PRP. When platelets in the autologous PRP get activated, platelet gel is formed $^{18}$. It was first developed in the early 1970s. The first clinical use of platelet-fibrinogen-thrombin mixture as a 'corneal adhesive' dates from 1975'2,19. In 1979, platelet 'gel foam' was used to obtain sutureless nerve 


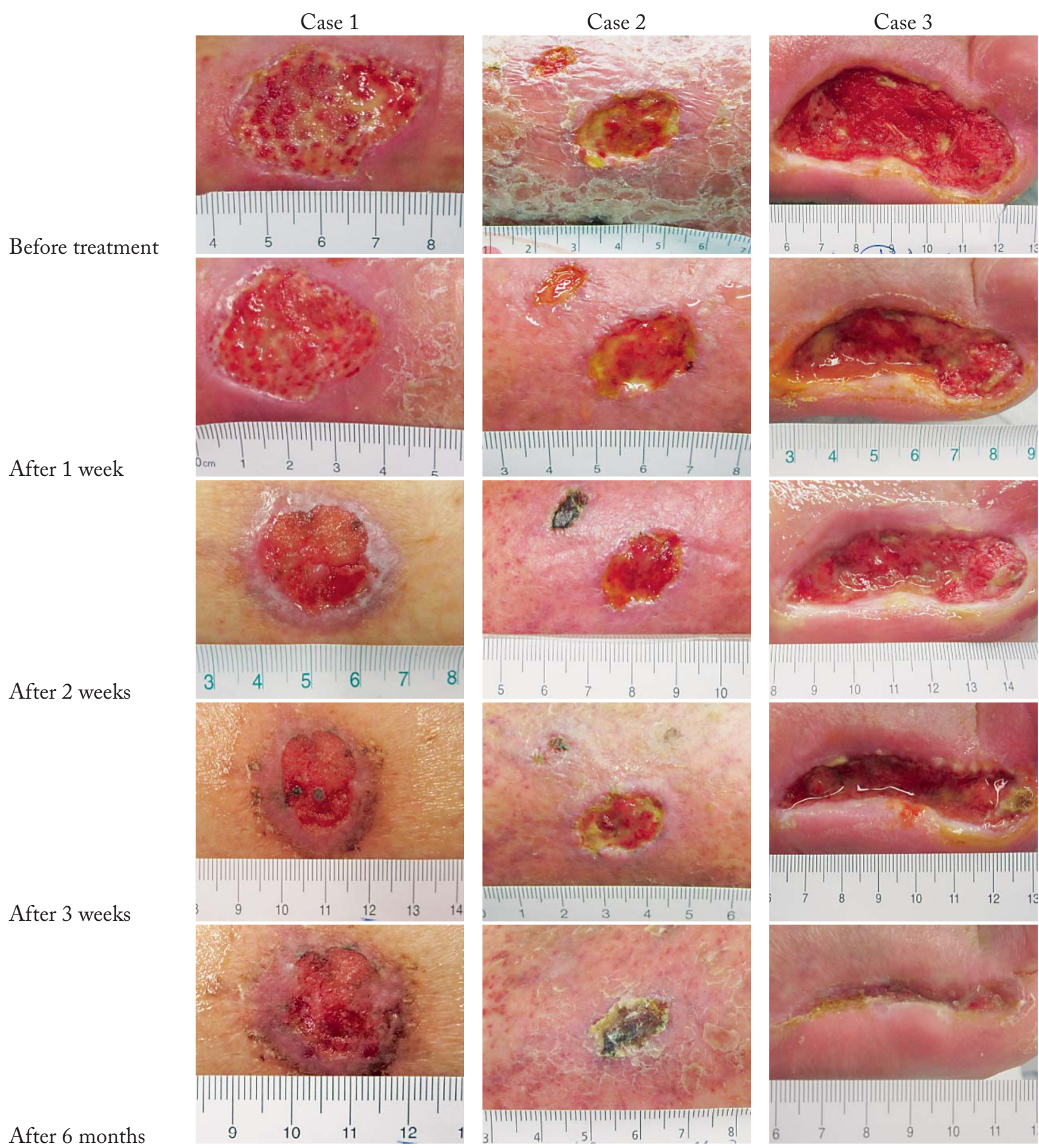

Fig. 1. Photo documentation on three cases treated with platelet gel.

anastomosis ${ }^{2,20}$. In recent years, the use of platelet gel has been extended to different surgical fields ${ }^{21}$. The fact that fibrin can drive fibroblast migration and collagen deposition, leading to granulation tissue formation, also offered the possibility of using platelet gel in the treatment of tissue defects ${ }^{2,22}$.
The strategy to promote wound healing is to prepare $\mathrm{PRP} /$ platelet gel and administer it to the sites of surgical interventions, injuries and chronic non-healing wounds, thus delivering growth factors directly to the wound site ${ }^{2,7}$. The mechanism of action is thought to be the molecular and cellular induction of normal 
Table 3. Microbiological characteristics before and after treatment

\begin{tabular}{|l|l|l|l|l|l|l|}
\hline Pathogen & $\begin{array}{l}\text { Experimental } \\
\text { group before } \\
\text { treatment } \\
(\mathrm{n}=30)\end{array}$ & $\begin{array}{l}\text { Experimental } \\
\text { group after } \\
\text { treatment } \\
(\mathrm{n}=30)\end{array}$ & $\mathrm{p}$ & $\begin{array}{l}\text { Control } \\
\text { group before } \\
\text { treatment } \\
(\mathrm{n}=30)\end{array}$ & $\begin{array}{l}\text { Control } \\
\text { group after } \\
\text { treatment } \\
(\mathrm{n}=30)\end{array}$ & $\mathrm{p}$ \\
\hline Pseudomonas aeruginosa & 8 & 7 & 0.573 & 12 & 13 & 0.326 \\
Morganella morganii & 4 & 3 & 0.326 & 4 & 4 & 1.000 \\
Escherichia coli & 6 & 7 & 0.326 & 4 & 4 & 1.000 \\
Staphylococcus aureus & 13 & 15 & 0.423 & 12 & 11 & 0.326 \\
Streptococcus agalactiae & 3 & 5 & 0.161 & 5 & 5 & 1.000 \\
Corynebacterium striatum & 2 & 1.000 & 4 & 4 & 1.000 \\
Stenotrophomonas maltophilia & 1 & 2 & 0.161 & 1 & 1 & 1.000 \\
Proteus mirabilis & 1 & 3 & 1.000 & 2 & 2 & 1.000 \\
Enterococcus faecalis & 2 & 1 & 0.326 & 1 & 1 & 1.000 \\
\hline
\end{tabular}

wound healing responses, similar to the one triggered by platelet activation ${ }^{18,23,24}$.

In addition to pain, chronic wounds on lower extremities also cause reduced mobility of the patient and, as such, strongly affect the quality of life ${ }^{25}$. Therefore, platelet gel was used for topical treatment of different chronic wounds. When autologous platelets were used for chronic venous leg ulcers in a randomized trial as adjuvant therapy, no significant effect on healing was observed $^{26}$. Similarly, there was no influence on healing of chronic venous ulceration in another randomized study using topical application of autologous platelet lysate ${ }^{27}$. In a systematic meta-analysis of the efficacy and safety of PRP, results showed no significant differences in complete epithelialization of skin ulcers between the experimental and control groups ${ }^{21}$.

More success has been achieved in the treatment of diabetic neuropathic foot ulcers ${ }^{28}$, where topically applied CT-102 APST significantly accelerated wound closure in diabetic leg ulcers ${ }^{29}$. This is of great importance because patients with diabetes mellitus have an increased risk of developing peripheral artery disease. Diabetes in association with critical ischemia of limbs is independently associated with an increased risk of mortality ${ }^{30}$.

A systematic review and meta-analysis in cutaneous hard-heal acute and chronic wounds demonstrated that PRP therapy improved complete and partial wound healing when compared with standard wound care $^{24,31}$.

In the platelet gel, autologous platelets are most commonly used. However, there are several advantages to the use of allogeneic platelets instead. Allogeneic platelet units from the blood bank are usually available in larger quantities, are safe, affordable and highly standardized in terms of platelet count, residual leukocyte and red blood cell content. In addition, the conditions for their preparation are mandated by international standards in the USA and Europe (the centrifugal forces used for their isolation, the temperature of centrifugation, techniques of separation and processing, and the composition of the preservative solution $)^{2,32}$.

Within the platelet gel, platelets are located in fibrin network, where they continually excrete bioactive substances and growth factors, which diffuse into the surrounding area $^{3}$. For optimization of activation and stability of the gel, we developed a new method. Besides commonly used activation of PRP with thrombin and calcium, we also added fibrinogen (factor 1) and factor XIII. The former was converted to fibrin by thrombin and the latter strengthened the cross-linking of fibrin molecules. We also added aprotinin, an antifibrinolytic molecule that inhibits proteolytic enzymes and thus slows down fibrinolysis and increases the consistency and stability of the platelet gel.

The characteristics of platelet products for transfusion are well specified while the minimum requirements for PRP are less clear ${ }^{33}$. Although there seems to be a consensus on the minimum number of platelets in the final product $^{13}$, there is much less information on the number of other blood cell types in the PRP that can have an effect on its efficacy. Leukocytes contain and produce cytokines that are catabolically active 
and might influence the inflammatory phase of the wound-healing process but they can also have an important antimicrobial role in $\mathrm{PRP}^{34}$. Therefore, we wanted to ensure at least minimal standardization of the PRPs we used. Since single donor platelets are a standard blood bank product, residual white and red blood cell content is highly standardized ${ }^{35}$. The maximum amount of the red and white blood cells in PRP was therefore determined based on the standard ${ }^{36}$.

Laboratory blood tests (complete blood count, electrolytes, urea, creatinine, albumins, proteins, iron, $\mathrm{C}$-reactive protein, erythrocyte sedimentation rate, liver function tests, tests of hemostasis) were carried out in order to detect the possible systemic effects of platelet gel and hydrogel treatment. We found that the results were similar before and after treatment in all cases, which means that the use of hydrogel and allogeneic platelet gel had no systemic effects.

Our results suggest that the new method of PRP activation using not only a combination of calcium and thrombin, but also aprotinin, fibrinogen and $\mathrm{co}^{-}$ agulation factor XIII, is more efficient in treating chronic ulcers of different etiologies. We upgraded the formula of precursors and increased stability of the platelet gel. The modern non-adhesive dressings absorb the new harder formula of platelet gel less than liquid form, so it stays on the wound longer when compared to the standard liquid consistency. Consequently, its effects also last longer. This therapy is safe and painless and the patient can be followed up in an outpatient clinic. The improved method could be an alternative treatment option for non-healing chronic wounds where other methods have failed.

In the so far published literature, PRP in wound healing of different etiology shows promising results $^{11,37-40}$, and so do the results of our study. This method is superior to others because of increased stability of platelet gel with prolongation of the effect. It could be the gold standard of treatment option.

In the past years, quality of life has gained ever more attention in medicine, and patients treated with PRP heal faster, returning to normal life and its quality.

\section{References}

1. Everts PA, Knape JT, Weibrich G, Schönberger JP, Hoffmann J, Overdevest EP, Box HA, van Zundert A. Platelet-rich plasma and platelet gel: a review. J Extra Corpor Technol. 2006; 38(2):174-87.
2. Rožman P, Semenič D, Smrke DM. The role of platelet gel in regenerative medicine. In: Wislet $\mathrm{S}$, editor. Advances in Regenerative Medicine. InTechOpen, 2011; p. 15, http://dx.doi. org/10.5772/26130

3. Rožman P, Bolta Z. Use of platelet growth factors in treating wounds and soft-tissue injuries. Acta Dermatovenereol Alp Pannonica Adriat. 2007;16(4):156-65.

4. Golebiewska EM, Poole AW. Platelet secretion: from haemostasis to wound healing and beyond. Blood Rev. 2015;29: 153-62, http://dx.doi.org/10.1016/j.blre.2014.10.003

5. Borst S, Sim X, Poncz M, French DL, Gadue P. Induced pluripotent stem cell-derived megakaryocytes and platelets for disease modeling and clinical use. Arterioscler Thromb Vasc Biol. 2017;37(11):2007-13, http://dx.doi.org/10.1161/ATVBAHA.117.309197

6. Wasterlain AS, Braun HJ, Dragoo JL. Contents and formulations of platelet-rich plasma. Oper Tech Orthop. 2012;22(1): 33-42, http://dx.doi.org/10.1053/j.oto.2011.11.001

7. Piccin A, Di Pierro AM, Canzian L, Primerano M, Corvetta D, Negri G, Mazzoleni G, Gastl G, Steurer M, Gentilini I, Eisendle K, Fontanella F. Platelet gel: a new therapeutic tool with great potential. Blood Transfus. 2017;15(4):333-40, http://dx.doi.org/10.2450/2016.0038-16

8. Ahmed M, Reffat SA, Hassan A, Eskander F. Platelet-rich plasma for the treatment of clean diabetic foot ulcers. Ann Vasc Surg. 2017;38:206-11, http://dx.doi.org/10.1016/j.avsg.2016.04.023

9. Gobbi G, Vitale M. Platelet-rich plasma preparations for biological therapy: applications and limits. Oper Tech Orthop. 2012;22(1):10-5, http://dx.doi.org/10.1053/j.oto.2012.01.002

10. Li JL, Zarbock A, Hidalgo A. Platelets as autonomous drones for hemostatic and immune surveillance. J Exp Med. 2017; 214(8):2193-204, http://dx.doi.org/10.1084/jem.20170879

11. Andia I, Sanchez M, Maffulli N. Basic science: molecular and biological aspects of platelet-rich plasma therapies. Oper Tech Orthop. 2012;22(1):3-9.

12. Pagel O, Walter E, Jurk K, Zahedi RP. Taking the stock of granule cargo: platelet releasate proteomics. Platelets. 2017;28(2): 119-28, http://dx.doi.org/10.1080/09537104.2016.1254762

13. Marx RE. Platelet-rich plasma: evidence to support its use. J Oral Maxillofac Surg. 2004;62(4):489-96, http://dx.doi.org/10.1016/j.joms.2003.12.003

14. De Pascale MR, Sommese L, Casamassimi A, Napoli C. Platelet derivatives in regenerative medicine: an update. Transfus Med Rev. 2015;29(1):52-61, http://dx.doi.org/10.1016/j.tmrv.2014.11.001

15. Alsousou J, Thompson M, Hulley P, Noble A, Willett K. The biology of platelet-rich plasma and its application in trauma and orthopaedic surgery: a review of the literature. J Bone Joint Surg Br. 2009;91(8): 987-96, http://dx.doi.org/10.1302/0301620X.91B8.22546

16. Anitua E, Andia I, Ardanza B, Nurden P, Nurden AT. Autologous platelets as a source of proteins for healing and tissue re- 
generation. Thromb Haemost. 2004;91(1):4-15, http://dx.doi. org/10.1160/THS10-11-0720

17. Mehta S, Watson JT. Platelet rich concentrate: basic science and current clinical applications. J Orthop Trauma. 2008;22 (6):432-8, http://dx.doi.org/10.1097/BOT.0b013e31817e793f

18. Özgürtaş T, Burkay U, Cemil Y. Platelet-Rich Plasma. Musculoskeletal Research and Basic Science. Springer International Publishing, 2016; p. 283-8. http://dx.doi.org/10.1007/978-3319-20777-3_16

19. Rosenthal AR, Harbury C, Egbert PR, Rubenstein E. Use of a platelet-fibrinogen-thrombin mixture as a corneal adhesive: experiments with sutureless lamellar keratoplasty in the rabbit. Invest Ophthalmol. 1975;14(11):872-5.

20. Fischer H. A method of suture-free anastomosis of nerve transplantation is being reported, using facial nerve as the example. Laryngol Rhinol Otol. 1979;58(2):154-6.

21. Martínez Zapata MJ, Martí Carvajal A, Solà I, Bolibar I, Angel Expósito J, Rodriguez L, García J. Efficacy and safety of the use of autologous plasma rich in platelets for tissue regeneration: a systematic review. Transfusion. 2009;49(1):44-56, http://dx.doi.org/10.1111/j.1537-2995.2008.01945.x

22. Brandstedt S, Rank F, Olson PS. Wound-healing and formation of granulation tissue in normal and defibrinogenated rabbits - an experimental model and histological study. Eur Surg Res.1980;12(1):12-21, http://dx.doi.org/10.1159/000128105

23. Reese RJ. Autologous platelet rich plasma (PRP): what do we know? Important concepts relevant to hair restoration surgery. Hair Transplant Forum Int. 2010;14-7.

24. Carter MJ, Fylling CP, Parnell LK. Use of platelet rich plasma gel on wound healing: a systematic review and meta-analysis. Eplasty. 2011;11:382-410.

25. Brtan Romić R, Brtan A, Romić I, Cvitanović H, Duvančić T, Lugović-Mihić L. Quality of life and perception of disease in patients with chronic leg ulcer. Acta Clin Croat. 2015;54(3): 309-14.

26. Senet P, Bon FX, Benbunan M, Bussel A, Traineau R, Calvo F, Dubertret L, Dosquet C. Randomized trial and local biological effect of autologous platelets used as adjuvant therapy for chronic venous leg ulcers. J Vasc Surg. 2003;38(6):1342-8, http://dx.doi.org/10.1016/S0741-5214(03)00908-X

27. Stacey MC, Mata SD, Trengove NJ, Mather CA. Randomised double-blind placebo controlled trial of topical autologous platelet lysate in venous ulcer healing. Eur J Vasc Endovasc Surg. 2000;20(3):296-301, http://dx.doi.org/10.1053/ejvs.2000.1134

28. Margolis DJ, Kantor J, Santanna J, Strom BL, Berlin JA. Effectiveness of platelet release for the treatment of diabetic neuropathic foot ulcers. Diabetes Care. 2001;24:483-8, http:// dx.doi.org/10.2337/diacare.24.3.483
29. Steed DL, Goslen JB, Holloway GA, Malone JM, Bunt TJ, Webster MW. Randomized prospective double-blind trial in healing chronic diabetic foot ulcers. CT-102 activated platelet supernatant, topical versus placebo. Diabetes Care. 1992;15: 1598-604.

30. Vrsalović M, Vučur K. Diabetes and critical limb ischemia: the deadly duo in patients with symptomatic peripheral artery disease. Acta Clin Croat. 2016;55(2):240-6, http://dx.doi.org/10.20471/acc.2016.55.02.09

31. Cohn CS, Lockhart E. Autologous platelet-rich plasma: evidence for clinical use. Curr Opin Hematol. 2015;22:527-32, http://dx.doi.org/10.1097/MOH.0000000000000183

32. Brecher ME. Technical Manual, $15^{\text {th }}$ edn. Bethesda, USA: American Association of Blood Banks, 2005; p. 196-7, http:// dx.doi.org/10.18203/2320-1770.ijrcog20160593

33. Dhurat R, Sukesh MS. Principles and methods of preparation of platelet-rich plasma: a review and author's perspective. J Cutan Aesthet Surg. 2014;7(4): 189-97, http://dx.doi.org/ 10.4103/0974-2077.150734

34. Wasterlain AS, Braun HJ, Dragoo JL. Contents and formulations of platelet-rich plasma. Oper Tech Orthop. 2012;22(1): 33-42, http://dx.doi.org/10.1053/j.oto.2011.11.001

35. Smrke D, Gubina B, Domanovic D, Rozman P. Allogeneic platelet gel with autologous cancellous bone graft for the treatment of a large bone defect. Eur Surg Res. 2007;39(3):170-74, http://dx.doi.org/10.1159/000100490

36. European Committee on Blood Transfusion. Guide to the Preparation, Use and Quality Assurance of Blood Transfusion, $14^{\text {th }}$ edn. 2008; p. 149, http://dx.doi.org/101111 j1423 0410200700965x

37. Picard F, Hersant B, Bosc R, Meningaud RP. Should we use platelet-rich plasma as an adjunct therapy to treat 'acute wounds' 'burns' and 'laser therapies': a review and a proposal of a quality criteria checklist for further studies. Wound Repair Regen. 2015;23:163-70, http://dx.doi.org/10.1111/wrr.12266

38. Picard F, Hersant B, Bosc R, Meningaud JP. The growing evidence for the use of platelet-rich plasma on diabetic chronic wounds: a review and a proposal for a new standard care. Wound Repair Regen. 2015;23(5):638-43, http://dx.doi.org/ 10.1111/wrr.12317

39. Moghazy AM, Ellabban, Adly OA, Ahmed FY. Evaluation of the use of vacuum-assisted closure (VAC) and platelet-rich plasma gel (PRP) in management of complex wounds. Eur J Plast Surg. 2015;38(6):463-70, http://dx.doi.org/10.1007/ s00238-015-1140-z

40. Biglari B, Reitzel T, Swing T, Büchler A, Gerner HJ, Schmidmaier M, Moghaddam A. A pilot study on the effectiveness of platelet-rich plasma and debridement for the treatment of nonhealing fistulas in spinal cord-injured patients. Adv Skin Wound Care. 2015;28(3):123-8, http://dx.doi.org/10.1097/01. ASW.0000459845.95441.1a 


\title{
Sažetak \\ USPJEŠNOST LIJEČENJA KRONIČNIH RANA ALOGENIM TROMBOCITNIM GELOM U USPOREDBI S HIDROGELOM: PROSPEKTIVNO ISTRAŽIVANJE
}

\author{
D. Semenič, T. Cirman, P. Rožmani D. M. Smrke
}

Cilj ove studije bio je procijeniti djelotvornost i sigurnost nove metode aktivacije plazme bogate trombocitima u obliku trombocitnog gela koji se rabi za liječenje kroničnih ulkusa potkoljenice koji ne cijele. Studija je bila prospektivno randomizirana, dvostruko slijepa i placebom kontrolirana. Liječili smo 60 bolesnika (42 muškarca, 18 žena, srednje dobi od 69,43 godine, SD 14,74) s kroničnim ulkusima potkoljenice različitih etiologija. Po 30 bolesnika liječeno je alogenim trombocitnim gelom odnosno hidrogelom. Obje skupine bile su usporedive po trajanju ulkusa i njegovoj veličini. Liječenje se ponavljalo jednom tjedno tijekom tri uzastopna tjedna i tada je posljednji pregled obavljen 6 mjeseci od prve primjene trombocitnog gela. Za analizu nezavisnih uzoraka primijenjen je t-test. Liječenje kroničnih rana trombocitnim gelom bilo je statistički značajno učinkovitije u odnosu na liječenje hidrogelom $(p<0,05)$. Šest mjeseci nakon aplikacije gela srednja vrijednost površine rana u eksperimentalnoj skupini smanjila se na $35,01 \%$ (SD 53,69) početne veličine rane. U kontrolnoj skupini područje rana smanjilo se na 89,95\% (SD 71,82), p=0,001. Opseg rana smanjio se na 54,62\% (SD 39,85) početne vrijednosti u eksperimentalnoj skupini u usporedbi s $91,28 \%$ (SD 29,32) u kontrolnoj skupini ( $<<0,001)$. Alogeni trombocitni gel pripremljen novom metodom koja se rabila u ovom istraživanju dobar je izbor za liječenje kroničnih rana koje ne cijele kada druge metode nisu učinkovite.

Ključne riječi: Plazma bogata trombocitima; Noga, čir; Rana, cijeljenje 